\title{
POLA KUMAN DAN RESISTENSINYA TERHADAP ANTIBIOTIKA DARI SPESIMEN PUS DI RSUD Dr. MOEWARDI TAHUN 2012
}

\section{MICROBIAL PATTERNS AND ANTIBIOTIC RESISTANCE OF ISOLATES COLLECTED FROM SPECIMEN PUS IN Dr. MOEWARDI HOSPITAL PERIOD 2012}

\author{
Busyron Chudlori ${ }^{1}$, M Kuswandi $^{2}$, Peni Indrayudha ${ }^{1 *}$ \\ ${ }^{1}$ Fakultas Farmasi, Universitas Muhammadiyah Surakarta \\ ${ }^{2}$ Fakultas Farmasi, Universitas Gadjah Mada \\ peni.indrayudha@gmail.com
}

\begin{abstract}
ABSTRAK
Resistensi terhadap antibiotika merupakan problem yang sering terjadi di seluruh dunia termasuk Indonesia. Pola resistensi ini selalu mengalami pergeseran dan perubahan dari setiap periode pemeriksaan. Oleh karena itu perlu suatu usaha untuk mencegah dan mengatasi munculnya resistensi bakteri dengan monitoring pemakaian antibiotika dibidang kesehatan. Penelitian ini bertujuan untuk mengetahui pola kuman dan resistensinya terhadap antibiotika dari spesimen pus di RSUD Dr. Moewardi. Ketepatan penentuan diagnosis dan pemilihan antibiotika berdasarkan uji resistensi sangat membantu dalam penatalaksanaan dan efektifitas terapi. Penelitian dilakukan di Laboratorium Mikrobiologi Klinik RSUD Dr. Moewardi dan Laboratorium Mikrobiologi Kedokteran UNS Surakarta. Spesimen yang digunakan berupa pus (nanah) pasien yang berkunjung atau dirawat di RSUD Dr. Moewardi periode Agustus-Oktober 2012. Jumlah sampel 53, isolasi dan identifikasi dilakukan sesuai standard laboratorium, ditambah dengan data sekunder hasil uji kuman. Uji kepekaan menggunakan metode disc diffusion pada media agar Mueller Hinton. Hasil penelitian menunjukkan dari total sampel yang diisolasi, terdiri dari kuman Gram negatif (66,04\%) dan kuman Gram positif (33,96\%). Kuman Staphylococcus aureus dominan ditemukan pada spesimen pus (30,19\%). Bakteri S. aureus resisten terhadap amoksisilin (93,75\%) dan tetrasiklin (87,5\%). Kuman Gram negatif Acinetobacter baumanni menunjukkan resistensi tinggi (100\%) terhadap siprofloksasin, amoksisilin, gentamisin dan sefotaksim.
\end{abstract}

Kata kunci : Antibiotika, Resistensi, Staphylococcus aureus, Acinetobacter baumanni, pus.

\section{ABSTRACT}

Resistance to antibiotics is a common problem throughout the world, including Indonesia. The pattern of resistance is always shifting and alteration of any examination period. Therefore it is necessary in an effort to prevent and cope with the emergence of bacterial resistance to the use of antibiotics in health monitoring. This study aimed to determine the pattern of bacteria and resistance to antibiotics of pus specimens Hospital Dr. Moewardi. The accuracy of determining the diagnosis and antibiotic selection based on resistance testing is helpful in the management and effectiveness of therapy. The study was conducted at the Clinical Microbiology Laboratory of Hospital Dr. Microbiology and Laboratory Medicine Moewardi UNS Surakarta. Specimens used in the form pus (pus) or visiting patients treated in hospitals Dr. Moewardi the period August to October 2012. Number of samples 53, isolation and done according to standard laboratory identification, coupled with secondary data test results germs. Sensitivity test using disc diffusion method on Mueller Hinton agar. The results showed that isolated from the total sample, consisting of Gram-negative bacteria (66.04\%) and Gram-positive bacteria (33.96\%). Staphylococcus aureus was predominantly found in the pus specimens (30.19\%). Staphylococcus aureus resistant to amoxicillin (93.75\%) and tetracycline (87.5\%). Gram-negative bacteria Acinetobacter baumanni showed high resistance (100\%) to ciprofloxacin, amoxicillin, gentamicin and cefotaxime.

Keywords: Antibiotics, resistance, Staphylococcus aureus, Acinetobacter baumanni, pus.

\section{PENDAHULUAN}

Sepanjang sejarah manusia, jutaan orang meninggal dunia akibat infeksi bakteri. Infeksi dapat menular dari satu orang ke orang lain atau dari hewan ke manusia (Jawetz et al., 2001). Prevalensi penyakit infeksi belum menunjukkan penurunan dari tahun ke tahun. Salah satu faktor penyebab tingginya kasus infeksi adalah pemakaian antibiotika yang telah resisten (Soleha et al., 2009).

Sekitar 30\% kejadian infeksi di Amerika Serikat berasal dari rumah sakit (nosocomial 
infection). Bakteri Gram negatif yang sering menyebabkan infeksi adalah Pseudomonas aeruginosa, Acinetobacter baumanni, Enterobacteria penghasil ESBL (Extended Spectrum Beta Laktamase) atau karbapenemase dan Escherichia coli. Di Indonesia, bakteri Gram negatif yang sering menjadi penyebab infeksi nosokomial cenderung resisten terhadap antibiotik yang digunakan (Bela, 2011).

Bakteri patogen lain yang sering menyebabkan tingginya kejadian infeksi nosokomial adalah $S$. aureus (Tseng et al., 2004) yang bertanggung jawab atas $80 \%$ penyakit supuratif pada permukaan kulit (Nickerson et al., 2009) yang berakibat kematian dapat sembuh dan memperlama kelangsungan hidup manusia (Kuswandi, 2011).

Sebagian besar penggunaan antibiotika terjadi di rumah sakit, namun tidak semua mempunyai suatu program untuk mengontrol infeksi dan pengawasan terhadap kuman resisten (Refdanita et al., 2004). Masa kejayaan antibiotika mulai hilang setelah dilaporkan bahwa antibiotika tidak mampu mengatasi beberapa bakteri patogen karena mulai resisten terhadap antibiotika (Kuswandi, 2011).

Hal tersebut menjadi masalah serius mengingat besarnya resiko resistensi dilihat dari segi finansial. Seorang pasien yang terinfeksi bakteri S.aureus resisten terhadap metisilin kemungkinan akan mati dan harus mengeluarkan biaya tambahan 4000 dolar lebih mahal dibandingkan pasien yang terinfeksi S.aureus sensitif terhadap antibiotika. Di Indonesia, Amelia (2007) menyebutkan bahwa dari 21 isolat pus pasien di Rumah Sakit Islam Kustati Surakarta 19 diantaranya terdapat bakteri S.aureus dan 52,6\% multiresisten antibiotik.

Perlu suatu usaha untuk mencegah resistensi bakteri dengan pengawasan penggunaan antibiotika seiring pola resistensi kuman yang selalu berubah di setiap waktu. Proses monitoring ini menyediakan informasi kuman patogen, membantu penentuan terapi antibiotika empiris yang memadai, menekan tingkat resistensi kuman dan meningkatkan efisiensi biaya terapi.

\section{METODE PENELITIAN \\ Alat dan Bahan}

Alat: Kapas lidi steril, inkubator (Memmert), mikroskop (Olympus CX21), alatalat gelas (Pyrex), autoklaf (All American), penangas air, mikropipet (Socorex), mesin vitex (Vitex 2 compact).

Pus diperoleh dari Laboratorium Mikrobiologi Klinik RSUD Dr. Moewardi sebanyak 10 sampel dan data sekunder medical record pasien yang mempunyai hasil uji kuman dan kepekaan. Media agar darah, Nutrient Agar (NA), Media MSA dan media agar Mueller Hinton, BHI, $\mathrm{NaCl}$, Cat Gram A, cat Gram B, cat Gram C, cat Gram D, minyak imersi, disk antibiotik siprofloksasin (5 $\mu \mathrm{g})$, eritromisin $(15 \mu \mathrm{g})$, amoksisilin $(25 \mu \mathrm{g})$, gentamisin $(10 \mu \mathrm{g})$, tetrasiklin $(30 \mu \mathrm{g})$, vankomisin $(30 \mu \mathrm{g})$, imipenem $(10 \mu \mathrm{g})$, dan sefotaksim $(30 \mu \mathrm{g})$.

\section{Jalannya penelitian}

Spesimen pus sebanyak 10 sampel yang diperoleh dari Laboratorium Mikrobiologi Klinik RSUD Dr. Moewardi diisolasi, diidentifikasi dan dilakukan pemurnian sehingga kuman yang akan diteliti adalah merupakan koloni tunggal, dan sampel diuji menggunakan alat Vitex. Proses identifikasi meliputi pemeriksaan mikroskopis, dan pewarnaan Gram.

Uji Manitol dengan Manitol Salt Agar (MSA) untuk membedakan $S$. aureus dengan bakteri Staphlococcus yang lain.

Kuman atau bakteri koloni tunggal dibiakkan dengan media NA (Nutrient Agar) miring untuk selanjutnya dibawa ke Laboratorium Mikrobiologi Fakultas Kedokteran Universitas Negeri Sebelas Maret Surakarta untuk diuji kepekaanya. Pengujian kepekaan kuman dilakukan menurut difusi cakram dan intrepetasi hasil mengacu pada CLSI (Clinical and Laboratory Standards Institute) dan standard intrepetasi di RSUD Dr. Moewardi (Goswami et al., 2011).

Koloni diambil dengan ose steril disuspensikan ke dalam $\mathrm{NaCl}$ dibandingkan kekeruhan standar Mc Farland, selanjutnya digoreskan di atas media penyubur $\mathrm{MH}$ dan disk antibiotika dari delapan golongan yang berbeda diletakkan di permukaan media. Setelah diinkubasi semalam, keesokan hari diukur diameter zona hambatnya.

\section{Analisis data}

Hasil Uji kepekaan yang diperoleh meliputi kuman sensitif (S), Intermediet (I) dan Resisten ( $R$ ) terhadap antibiotika. Dari data yang diperoleh dibuat presentase perbandingan hasil uji kepekaan dengan total isolat dikalikan seratus persen.

\section{HASIL DAN PEMBAHASAN}

1. Distribusi pemeriksaan pus pasien menurut usia dan jenis kelamin

Hasil analisis deskriptif terhadap karakteristik pasien menunjukkan bahwa mayoritas pasien yang dilakukan pemeriksaan pus berjenis kelamin laki-laki sebesar 55,32\%, sedangkan jenis kelamin wanita hanya $44,68 \%$ (Tabel 1). 
Tabel 1- Distribusi pemeriksaan pus pasien menurut usia dan jenis kelamin di RSUD Dr. Moewardi periode AgustusOktober 2012

\begin{tabular}{cccc}
\hline Parameter & Pasien & Jumlah & Persentase (\%) \\
\hline Usia & $1-12$ & 2 & 4,26 \\
(tahun) & $>12-18$ & 3 & 6,38 \\
& $>18-60$ & 33 & 70,21 \\
Jenis & $>60$ & 9 & 19,15 \\
Kelamin & Laki-laki & 26 & 55,32 \\
& Perempuan & 21 & 44,68
\end{tabular}

\section{Distribusi kuman patogen yang diisolasi} dari spesimen pus

Hasil isolasi kuman dari spesimen pus di Laboratorium Mikrobiologi Klinik RSUD Dr. Moewardi periode Agustus-Oktober 2012 menunjukkan bahwa dari 53 isolat ditemukan dua jenis kuman yaitu kuman Gram positif dan Gram negatif. Kuman Gram positif yang dapat diisolasi selama penelitian ini adalah $S$. aureus dan S. haemolyticus, sedangkan kuman Gram negatif yang dapat diisolasi antara lain: $A$. baumanni, E. coli, Klebsiella pneumonia, Pseudomonas aeruginosa, Enterobacter cloacae, Proteus mirabilis, Proteus vulgaris, Serratia marcescens, Morganella morgani, Providencia stuartii. Hasil isolasi kuman dari spesimen pus terbanyak ditunjukkan oleh $S$. aureus (30,19\%) diikuti kuman Gram negatif $A$. baumanni $(15,09 \%)$ dan E. coli $(15,09 \%), K$. pneumonia $(11,33 \%)$, dan $P$. aeruginosa (5,66\%) (Tabel 2).

Tabel 2- Pola kuman patogen yang diisolasi dari spesimen pus di RSUD Dr. Moewardi periode Agustus-Oktober 2012

\begin{tabular}{lcc}
\hline Nama bakteri & Jumlah & Presentase (\%) \\
\hline S. aureus & 16 & 30,19 \\
S. haemolyticus & 2 & 3,77 \\
A. baumanni & 8 & 15,09 \\
E. coli & 8 & 15,09 \\
K. pneumonia & 6 & 11,33 \\
P. aeruginosa & 3 & 5,66 \\
E. cloacae & 2 & 3,77 \\
P. mirabilis & 3 & 5,66 \\
P. vulgaris & 1 & 1,89 \\
S. marcescens & 2 & 3,77 \\
P. stuartii & 1 & 1,89 \\
M. morgani & 1 & 1,89 \\
\hline Jumlah & 53 & 100 \\
\hline
\end{tabular}

Bakteri $S$. aureus merupakan patogen yang sering ditemukan pada spesimen pus, penyebarannya pada permukaan kulit sebagai flora normal terutama di sekitar hidung, mulut, alat kelamin dan anus. Bakteri ini menjadi penyebab infeksi pada luka abses yang merupakan kumpulan nanah atau cairan dalam jaringan yang disebabkan oleh infeksi. Bakteri ini mempunyai kemampuan untuk mengembangkan daya resistensi yang cepat terhadap antibiotika, respon defensif sebagai konsekuensi dari akuisisi dan transfer plasmid resistensi antibiotika melalui mekanisme resistensi intrinsik (Onwukibo, 2011).
3. Distribusi kuman Gram Positif dan Gram negatif

Distribusi kuman Gram negatif berjumlah 35 isolat dan Gram positif sebanyak 18 isolat. Dari hasil tersebut didapatkan rasio antara kuman Gram negatif dan Gram positif adalah 35:18 atau 2:1 (Gambar 1).

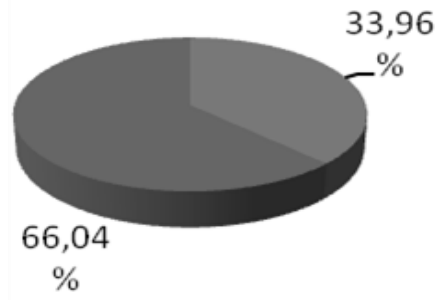

Gambar 1- Distribusi kuman Gram positif dan Gram negatif yang diisolasi dari spesimen pus di RSUD Dr. Moewardi periode Agustus-Oktober 2012

Distribusi kuman Gram negatif mencapai $66,04 \%$ terdiri dari sepuluh macam kuman dengan $A$. baumanni dan $E$. coli sebagai kuman yang sering muncul $(22,85 \%)$ diikuti $K$. pneumonia $(17,14 \%)$, P. aeruginosa $(8,57 \%)$, E. cloacae $(5,71 \%)$, P. $(8,57 \%)$, P. vulgaris $(2,85 \%)$, S. marcescens $(5,71 \%)$, P. stuartii (2,85\%) dan M. morgani (2,85\%) (Tabel 3).

Acinetobacter baumanni merupakan bakteri Gram negatif yang sering berperan dalam infeksi nosokomial. Bakteri ini sangat berbahaya dan berpotensi untuk menjadi resisten terhadap banyak antibiotik, sering ditemukan di daerah tubuh yang lembab, seperti lipatan paha, sela-sela jari kaki, pada beberapa kasus juga ditemukan kolonisasi pada orang dewasa. Mekanisme terjadinya resistensi yaitu ekspresi efflux pump yang berlebihan atau menghasilkan enzim $\beta$ laktamase.

Tabel 3- Pola kuman Gram negatif yang diisolasi dari spesimen pus di RSUD Dr. Moewardi periode AgustusOktober 2012

\begin{tabular}{lcc}
\hline Kuman & Jumlah isolat pus & Presentase $(\%)$ \\
\hline A. baumanni & 8 & 22,85 \\
E. coli & 8 & 22,85 \\
K. pneumonia & 6 & 17,14 \\
P. aeruginosa & 3 & 8,57 \\
E. cloacae & 2 & 5,71 \\
P. mirabilis & 3 & 8,57 \\
P. vulgaris & 1 & 2,85 \\
S. marcescens & 2 & 5,71 \\
P. stuartii & 1 & 2,85 \\
M. morgani & 1 & 2,85 \\
\hline Jumlah & 35 & 100 \\
\hline
\end{tabular}

\section{Pola resistensi kuman Gram Positif terhadap beberapa antibotika}

Sebanyak delapan antibiotika diujikan pada kuman Gram positif Staphylococcus aureus, terdapat 3 antibiotika yang memiliki tingkat kepekaan diatas $50 \%$ yaitu vankomisin $(100 \%)$, siprofloksasin (75\%), gentamisin $(68,75 \%)$, diikuti eritromisin, imipenem dan sefotaksim $(50 \%)$ (Tabel 4$)$. 
Tabel 4- Rekapitulasi pola resistensi kuman Gram positif terhadap beberapa antibiotika dari spesimen pus di RSUD Dr. Moewardi periode Agustus-Oktober 2012

\begin{tabular}{ccccccccccc}
\hline Kuman Gram positif & Isolat pus & Hasil uji kuman & CIP & E & AMX & CN & TE & VA & IPM & CTX \\
\hline \multirow{2}{*}{ S. aureus } & \multirow{2}{*}{16} & Sensitif & 12 & 8 & 1 & 11 & 2 & 16 & 8 & 8 \\
S. haemolyticus & \multirow{2}{*}{2} & Resisten & 4 & 8 & 15 & 5 & 14 & 0 & 8 & 8 \\
& & Sensitif & 0 & 0 & 0 & 0 & 2 & 2 & 0 & 0 \\
& & Resisten & 2 & 2 & 2 & 2 & 0 & 0 & 2 & 2 \\
\hline
\end{tabular}

Keterangan: CIP: Siprofloksasin; E: Eritromisin; AMX: Amoksisilin; CN: Gentamisin; TE: Tetrasiklin; VAN: Vankomisin; IPM: Imipenem; CTX: Sefotaksim

Kepekaan sempurna ditunjukkan oleh vankomisin (100\%) yang merupakan antibiotika pilihan terakhir untuk kuman Gram positif $S$. aureus. Sedangkan tingkat resistensi tertinggi diberikan terhadap amoksisilin (93,75\%) diikuti oleh tetrasiklin (87,5\%). Tingginya angka resistensi disebabkan karena antibiotika ini paling sering digunakan untuk pengobatan (Gambar 2).

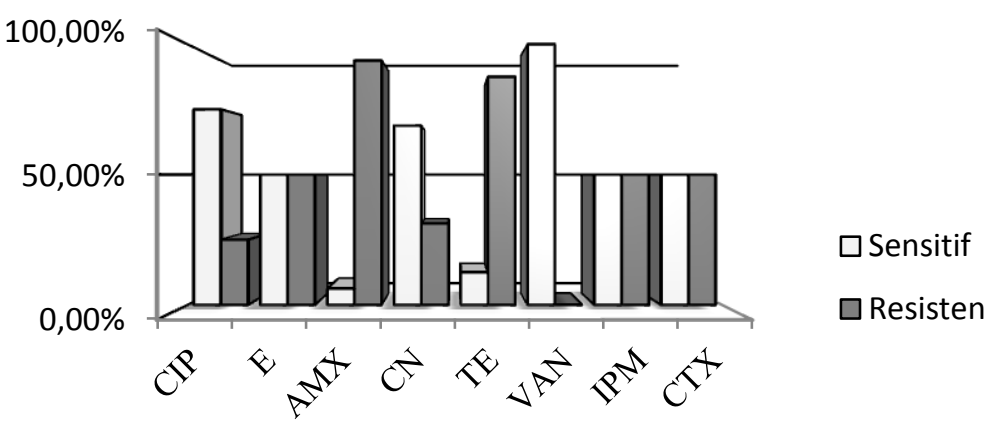

Gambar 2- Pola resistensi kuman Gram positif terhadap beberapa antibiotika dari spesimen pus di RSUD Dr. Moewardi periode agustus-oktober 2012. Keterangan: CIP: Siprofloksasin; E: Eritromisin; AMX: Amoksisilin; CN: Gentamisin; TE: Tetrasiklin; VAN: Vankomisin; IPM: Imipenem; CTX: Sefotaksim.

Amoksisilin merupakan antibiotika yang banyak tersedia pada unit-unit pelayanan kesehatan masyarakat terutama puskesmas dan rumah sakit untuk pasien menengah ke bawah sehingga paling banyak dipakai (Refdanita et al., 2009). Selain itu antibiotika ini juga digunakan untuk produksi ternak yang dilakukan oleh petani sehingga kurang pengawasan terhadap pemakaiannya. Hal ini merupakan salah satu penyalahgunaan antibiotika yang dapat menyebabkan terpaparnya kuman patogen oleh antibiotika yang kemudian menjadi resisten (Graves et al., 2011).

Proses resistensi Amoxicillin disebabkan karena kuman Staphylococcus aureus dapat menghasilkan enzim $\beta$-laktamase yang menyerang cincin $\beta$-laktam pada molekul penisilin. Enzim ini bertanggung jawab dalam peningkatan perlawanan terhadap penisilin. Enzim $\beta$-laktamase melindungi bakteri Gram positif dan Gram negatif. Dalam Gram positif, enzim dibebaskan kedalam medium dan menghancurkan antibiotika sebelum mencapai sel. Dalam Gram negatif enzim secara strategis terlokasi pada rute dimana antibiotik harus berjalan untuk mencapai targetnya (Johnson \& Livermore, 2001).
Mekanisme aksi Amoxicillin (penisilin) adalah dengan mencegah ikatan silang peptidoglikan pada tahap akhir sintesis dinding sel, yaitu dengan cara menghambat protein pengikat penisiln (penicillin binding protein). Protein ini merupakan enzim dalam membran plasma sel bakteri yang secara normal terlibat dalam penambahan asam amino yang berikatan silang dengan peptidoglikan dinding sel bakteri, dan mengeblok aktivitas enzim transpeptidase sehingga dinding sel bakteri menjadi rapuh dan mudah lisis (Pratiwi, 2008).

Bakteri $S$, aureus terhadap beberapa antibiotika menggunakan metode disc diffusion (Kirby-Bauer). Hasil uji kepekaan menunjukkan bahwa Staphylococcus aureus (161p) resisten terhadap tetrasiklin dengan diameter zona hambat $(11 \mathrm{~mm})$, sensitif terhadap siprofloksasin $(29 \mathrm{~mm})$, imipenem $(47 \mathrm{~mm})$, gentamisin $(23 \mathrm{~mm})$ dan vankomisin $(18 \mathrm{~mm})$. $S$. aureus (206p) masih tetap resisten terhadap tetrasiklin $(12 \mathrm{~mm})$. Pada kuman ini terdapat zona hambat yang cukup besar ditunjukkan imipenem (52 $\mathrm{mm})$, sedangkan vankomisin hanya memiliki zona hambat sebesar $21 \mathrm{~mm}$ meskipun sebenarnya merupakan antibiotika spektrum sempit untuk Staphylococcus aureus yang resisten terhadap penisilin (Gambar 3). 

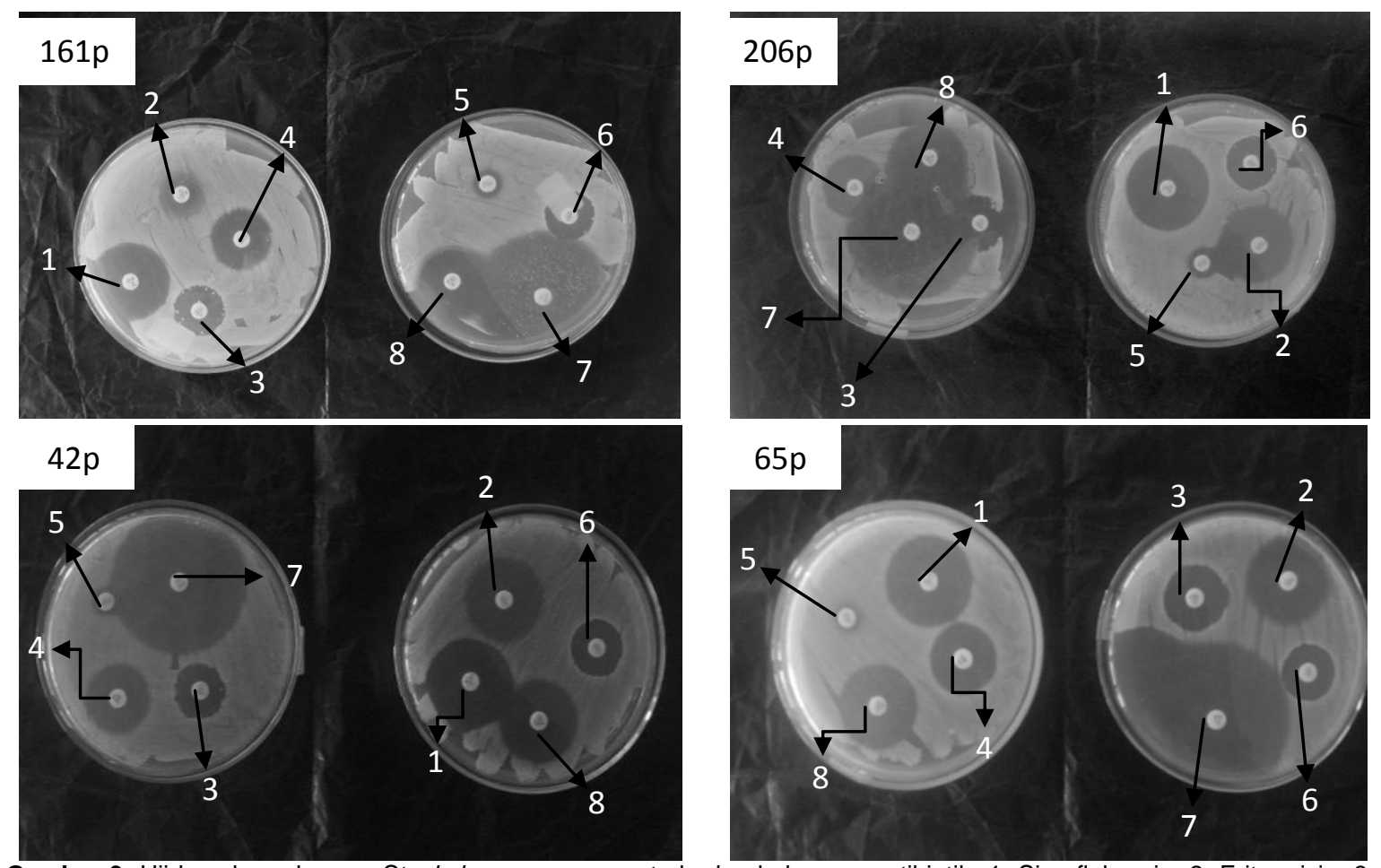

Gambar 3. Uji kepekaan kuman Staphylococcus aureus terhadap beberapa antibiotik, 1. Siprofloksasin; 2. Eritromisin; 3. Amoksisilin; 4. Gentamisin; 5. Tetrasiklin; 6. Vankomisin; 7. Imipenem; 8. Sefotaksim.

Staphylococcus aureus $42 p$ menunjukkan resistensinya terhadap tetrasiklin dengan diameter zona hambat sebesar $10 \mathrm{~mm}$. Hal yang sama ditunjukkan oleh $S$. aureus $65 p$ yang memiliki zona hambat terkecil sebesar 9 $\mathrm{mm}$. Berdasarkan hasil uji kepekaan tersebut, kuman $S$. aureus mempunyai tingkat resistensi tinggi terhadap tetrasiklin $(87,5 \%)$ (Tabel 5).

Tabel 5. Data zona hambat minimum tetrasiklin

\begin{tabular}{cccc}
\hline \multirow{3}{*}{ Bakteri } & $\begin{array}{c}\text { Kode } \\
\text { bakteri } \\
\text { uji }\end{array}$ & $\begin{array}{c}\text { Diameter } \\
\text { zona } \\
\text { hambat }\end{array}$ & Keterangan \\
\hline \multirow{3}{*}{ Staphylococcus } & $161 \mathrm{p}$ & $11 \mathrm{~mm}$ & Resisten \\
aureus & $206 \mathrm{p}$ & $12 \mathrm{~mm}$ & Resisten \\
& $42 \mathrm{p}$ & $10 \mathrm{~mm}$ & Resisten \\
& $65 \mathrm{p}$ & $9 \mathrm{~mm}$ & Resisten \\
\hline
\end{tabular}

Tetrasiklin merupakan antibiotik spektrum luas berperan menghambat sintesis protein bakteri dengan cara berikatan pada bagian $16 \mathrm{~S}$ ribosom subunit 30S, sehingga mencegah aminoasil-tRNA terikat pada situs aktif ribosom, ikatan ini secara alami bersifat reversible, mengganggu penempelan tRNA yang membawa asam amino ke ribosom 30S dari ribosom 70S, mencegah penambahan asam amino ke rantai polipeptida yang sedang tumbuh.

Sintesis protein (Translasi mRNA) merupakan penerjemahan urutan nukleotida yang ada pada molekul mRNA menjadi rangkaian asam amino yang menyusun suatu polipeptida atau protein. Perlu dipahami bahwa hanya molekul $m R N A$ yang ditranslasi, sedangkan $r R N A$ dan $t R N A$ tidak ditranslasi. Proses translasi berlangsung melalui empat tahapan utama, yaitu inisiasi, elongasi, translokasi, dan terminasi dengan tempat aksi antibiotika (Yuwono, 2009).

\section{Pola resistensi kuman Gram negatif terhadap beberapa antibiotika}

Pada pengujian total isolat Gram negatif Imipenem paling poten untuk menghambat pertumbuhan kuman Gram negatif dengan potensi kepekaan $(77,14 \%)$. Hasil ini sangat bertolak belakang dengan beberapa antibiotik lain yang hanya memiliki tingkat kepekaan dibawah $50 \%$. Kepekaan kuman total isolat Gram negatif terhadap ciprofloxacin $(42,85 \%)$, Gentamicin (40\%) dan cefotaxime (37,14\%). Adapun tingkat resistensi tertinggi masih ditunjukkan Amoxicillin (88,57\%). Kemungkinan tingginya tingkat resistensi Gram negatif ini dapat menjelaskan mengapa angka populasi kuman Gram negatif lebih banyak dibanding Gram positif, selain karena faktor endemik dan sifat endogen kuman itu sendiri. Antibiotik yang dipakai sebagian besar masyarakat secara bebas seperti amoxicillin, ampicillin dan tetracycline angka resistensi kuman Gram negatifnya sudah di atas 75\% (Rizal, 2010). 


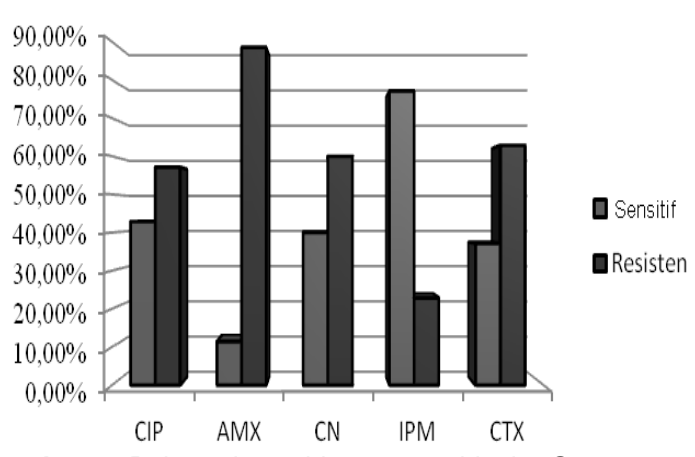

Gambar 4- Pola resistensi kuman total isolat Gram negatif, CIP: Siprofloksasin; AMX: Amoksisilin; CN: Gentamisin; IPM: Imipenem; CTX: Sefotaksim.

Bakteri Gram negatif yang paling sering muncul adalah $A$. baumanni $(22,85 \%)$, E. coli $(22,85 \%)$ dan K. pneumonia $(17,14 \%)$ (Tabel 3). Bakteri $A$. baumanni sangat resisten terhadap empat golongan antibiotika yang berbeda yaitu siprofloksasin (kuinolon), amoksisilin (penisilin), gentamisin (aminoglikosida) dan sefotaksim (sefalosporin), terhadap imipenem resistensinya hanya $50 \%$ (Gambar 5).

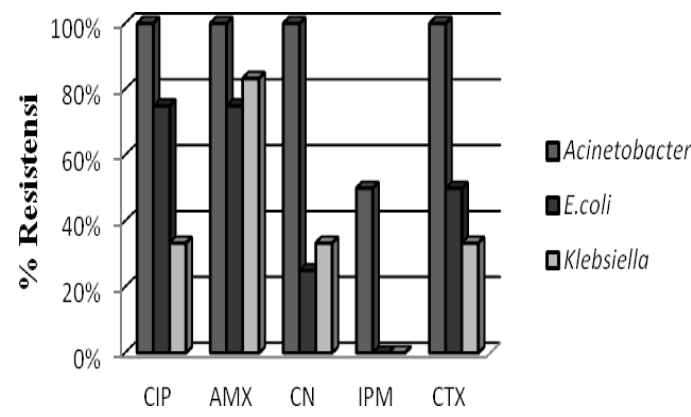

Gambar 5- Resistensi kuman Gram negatif yang terbanyak diisolasi dari pus, CIP: Siprofloksasin; AMX: Amoksisilin; CN: Gentamisin; IPM: Imipenem; CTX: Sefotaksim.

Escherichia coli kuman yang paling umum pada Gram negatif menunjukkan resistensi (75\%) terhadap Ciprofloxacin dan Amoxicillin. Hasil ini berbanding terbalik dengan apa yang telah ditunjukkan oleh kuman Gram positif Staphylococcus (Gambar 2) yang peka terhadap siprofloksasin (75\%), mengingat tingginya penggunaan Ciprofloxacin pada beberapa pengobatan. Antibiotika golongan kuinolon bersifat bakterisidal bekeria dengan menghambat enzim DNA girase pada replikasi DNA, sehingga akan menghambat proses replikasi DNA dan transkripsi mRNA (Pratiwi, 2008).

Sebagian besar perhatian pada timbulnya resistensi antibiotika dirumah sakit difokuskan pada organisme Gram positif dan antibiotika yang baru untuknya telah tersedia. Sebaliknya, sedikit sekali perhatian pada munculnya organisme Gram negatif yang sudah banyak resisten (Rizal, 2010). Beberapa studi di Amerika juga menunjukkan pola resistensi yang besar terhadap golongan kuinolon, sefalosporin dan aminoglikosida sedangkan resistensi golongan karbapenem lebih rendah jika dibandingkan sefalosporin dan kuinolon (McDonald, 2006).

Pemakaian antibiotika sefalosporin secara luas di rumah sakit menyebabkan munculnya resistensi $\alpha$-laktamase spektrum luas. Golongan karbapenem sebaiknya dijadikan antimikroba lini terakhir bagi Gram negatif mengingat kecerendungan resistensinya bukan pada golongan karbapenem saja, tetapi determinasi resistensinya juga pada golongan aminoglikosida dan kuinolon, selain perlu diingat sifat nefrotoksiknya (McDonald, 2006).

\section{KESIMPULAN}

1. Pola kuman yang diisolasi dari spesimen pus di RSUD Dr. Moewardi periode Agustus-Oktober 2012 adalah S. aureus dengan presentase $30,19 \%$ dan telah resisten terhadap beberapa antibiotika, khususnya terhadap Amoxicillin (93,75\%) dan Tetracycline $(87,5 \%)$.

2. Kuman Gram negatif yang paling banyak diisolasi dari spesimen pus adalah $A$. baumanni $(15,09 \%)$, E. coli $(15,09 \%)$ dan $K$. pneumonia $(11,33 \%)$. A. baumanni menunjukkan resistensi tinggi (100\%) terhadap siprofloksasin, amoksisilin, gentamisin dan sefotaksim.

\section{SARAN}

Perlu dikembangkan suatu strategi efektif guna membatasi resistensi antibiotika dengan menyertakan edukasi dan konseling pada masyarakat awam dan klinisi kesehatan dalam penggunanaan antibiotika. Pentingnya kontrol infeksi untuk mencegah transmisi bakteri dan virus. Dilakukan pemantauan pola kuman dan kepekaannya secara berkala dan berkesinambungan sebagai pedoman pemberian antibiotika dan penatalaksanaan penderita infeksi.

\section{DAFTAR PUSTAKA}

Amelia, E., 2007, Isolasi, Identifikasi \& Uji Sensitivitas Staphylococcus aureus dari Pus Pasien di Rumah Sakit Islam Kustati Surakarta terhadap Beberapa Antibiotik, Skripsi, Fakultas Farmasi, Universitas Muhammadiyah Surakarta.

Bela, B., 2011, Microbial and Susceptibility Pattern of Gram Negative Infection: Infection Diseases New Challenges New Solutions, Proceeding $12^{\text {th }}$ Jakarta Antimicrobial Update (JADE) 2011, Jakarta. 
Goswami, N. N., Trivedi, H. R., Goswami, A. P., Patel, T. K. \& Tripathi, C. B., 2011, Antibiotic Sensitivity Profile of Bacterial Pathogens in Postoperative Wound Infection at a Tertiary Care Hospital in Gujarat, India, Journal of Pharmacology and pharmacotherapeutics, 2, 158-164.

Graves, A. K., Liwimbi, L., Israel, L. D., Heugten, E. V., Robinson, B., Cahoon, C. W. \& Lubbers, J.F., 2011, Distribution of Ten Antibiotic Resistance Genes in E. coli Isolates from Swine Manure, Lagoon Effluent and Soli collected from a Lagoon Waste Application field, Folia Microbiol 56, 131137.

Jawetz, E., Melnick, J. L. \& Adelberg, E. A., 2001, Mikrobiologi Kedokteran, edisi pertama, diterjemahkan oleh bagian Mikrobiologi Fakultas Kedokteran UNAIR, 224-227, 233-235, Surabaya, Salemba Medika.

Johnson, A. P \& Livermore, D. M., 2001, Mechanisms of antibiotic resistance, In: Galey, H. F., Webster, N. R. \& Lawler, P. G. P., Antibiotic Resistance and Infection Control, London, BMJ Books.

Kuswandi, M., 2011, Strategi Mengatasi Bakteri yang Resisten terhadap Antibiotika, 10-12, Pidato pengukuhan jabatan guru besar pada Fakultas Farmasi Universitas Gadjah Mada, Yogyakarta.

McDonald, L. C., 2006, Trends in Antimicrobial Resistance in Health Care Associated Pathogens and Effect on Treatment, J Clinical Infectious Diseases, 42, 65-71.

Nickerson, E.K., West, T. E., Day, N. P. \& Peacock, S. J., 2009, Staphylococcus aureus Disease and Drug Resistance in Resource-Limited Countries in South and East Asia. Lancet infect Dis, 9 (130), 5.

Onwubiko, N. E. \& Sadiq, N. M., 2011, Antibiotic Sensitivity Pattern of Staphylococcus aureus from Clinical Isolates in a Tertiary Health Institution in Kano, Northwestern Nigeria, Pan African Medical Journal, 8, 4. http://www.panafrican-med-journal.com/content/article/8/4/full.

Pratiwi, S. T., 2008, Mikrobiologi Farmasi, Fakultas Farmasi Universitas Gadjah Mada, 154-160, Jakarta, Erlangga.

Refdanita., Maksum, R., Nurgani, A. \& Endang P., 2001, Pola Kepekaan Kuman Terhadap Antibiotika di Ruang Rawat Intensif Rumah Sakit Fatmawati Jakarta Tahun 2001-2002, Makara Kesehatan, 8 (2), 41-48.

Rizal, S., 2010, Pola Kuman dan Resistensi Antimikroba dari Berbagai Spesimen Pasien di RS Dr. Oen Solo Baru Kabupaten Sukoharjo, The Indonesian Journal of Medical Science, 1 (7), 392-399.

Soleha, M., Elvistra, H. L., Fitri, N. \& Triyani., 2009, Pola Resistensi Bakteri terhadap Antimikroba di Jakarta, Proceeding Puslitbang Biomedis dan Farmasi, Badan Litbang Kesehatan, Jakarta.

Tseng, C. W., Zhang, S., Steward, G. C., 2004, Accesory Gene Regulator Control of Staphylococcal Enterotoxin D gene Expression. J Bacteriology, 186, 1793-1801.

Yuwono, T., 2009, Biologi Molekular, Laboratorium Mikrobiologi Fakultas Pertanian Universitas Gadjah Mada, 209-215, Jakarta, Erlangga. 